\title{
Assessment of Value Added Tax on the Growth and Development of Nigeria Economy: Imperative for Reform
}

\author{
Dr.Adegbie, Folajimi Festus ${ }^{1}$ (PhD,MPhil,MBA,FCA,FCTI,FCIB), Jayeoba Olajumoke ${ }^{1}$ (Msc,ACA,ACTI) \& \\ Kwabai Jerry Danjuma ${ }^{1}$ (Msc) \\ ${ }^{1}$ Babcock University, Babcock Business School, Department Of Accounting, Ilishan-Remo, Ogun State, Nigeria \\ Correspondence: Dr.Adegbie, Folajimi Festus, Babcock University, Babcock Business School, Department Of \\ Accounting, Ilishan-Remo, Ogun State, Nigeria
}

Received: August 9, 2016

Accepted: October 26, 2016

Online Published: November 7, 2016

doi:10.5430/afr.v5n4p163

URL: http://dx.doi.org/10.5430/afr.v5n4p163

\begin{abstract}
Value Added Tax (VAT) is a consumption tax that is being charged and embraced by many developed and developing countries, which is relatively easy to administer and very difficult to evade. The economic development and growth of any nation depends on government ability to generate adequate revenue in order to effectively provide various infrastructural facilities to satisfy the needs of the population and takes its position among the nations in the global village. The global oil glut has adversely affected the revenue position of Nigeria. The over $60 \%$ drop in oil price to below $\$ 40$ per barrel was unanticipated by the government. This has resulted to over $80 \%$ fall in the yield(spread) per barrel of oil produced in Nigeria, steep decline in the country's revenue,2016 budget deficit of over N2trillion,continuing devaluation of the Naira, slowing Gross Domestic Product( GDP) growth, reduced inflow of foreign direct investment, rising inflation and growing unemployment. The government at the federal level has put a stop on capital projects, while allocation to the states of the federation has reduced resulting in the inability of many states provide relevant infrastructural facilities and pay workers' salaries ranging from five months to eight months. It is therefore very clear that there is the need to diversify the revenue base of the nation, and Value Added Tax (VAT) is a major revenue source of advanced nations of the world, which much attention is not focused on this area by the federal government of Nigeria. The main focus of this work was to evaluate the impact of VAT on Nigerian economy between its introduction to date to discover the imperativeness of its reform. Ex-post-factor, descriptive and analytical research approach were adopted for the work. Data of VAT and GDP were obtained from 1994-2015, and analyzed to determine the relationship that has been existing between them. It was discovered that VAT has a positive relationship with GDP. The coefficient of the model indicate that a $1 \%$ increase in VAT will lead to a $0.88 \%$ increase in GDP This shows a perfect positive correlation between VAT and GDP.It therefore becomes imperative for a reform in VAT.In conclusion,VAT is due for a total reform in rate and clear definition of exempted goods and services.We recommend that the curent $5 \%$ should be review upward to a minimum of $10 \%$,Integrated Tax Offices should be stenghtened to increase efficiency and effectiveness,Federal Inland Revenue Service should address tax evasion,government should use VAT revenue judiciously to encourage tax payers and government should clearly define excempted goods and services so as to charge vatable goods that are currently not vatable.
\end{abstract}

Keywords: Administration, Development, Growth, Reform,Optimal Tax, Integrated

\section{Introduction}

Value Added Tax (VAT) is a consumption tax that is being charged and embraced by many developed and developing countries, which is relatively easy to administer and very difficult to evade. Chartered Institute of Taxation CITN (2002) explained that the idea of introducing VAT in Nigeria came from the report of the study group set up by the Federal Government in 1991 to review the tax system in Nigeria, hence VAT was proposed and a committee reviewed its implementation. Value Added Tax Act 1993 was passed and thereby repealed Sales Tax Act of 1986.According to Federal Inland Revenue Service FIRS (1995) as cited by Bassey (2013),Value Added Tax is a consumption tax payable on the goods and services consumed by any person whether government agencies, business organizations or individuals. The dynamic operating mechanism of VAT is very easy because the yield from VAT is an accurate measurement of the growth of an economy since purchasing power increases with economic growth.VAT is a self-assessment tax that is paid when returns are being rendered to the government. In-built in the tax is the refund or credit mechanism which eliminates the waterfall effect that is feature of the retail sales tax. The 
input-output tax mechanism in VAT makes it self-policing because of the operating mechanism. In effect, it is the Out Tax less Input Tax that constitutes the VAT payable. It is the equivalent of the VAT paid by the final consumer of the product that is collected by the government. Although VAT is a multiple stage tax, it has a single effect and does not add more than the specified rate to the consumer price no matter the number of stages at which the tax is paid(CITN,2002).From the explanations, VAT is levied at each stage at which supplies change hands. Example is the case of a manufacturing concern which manufactures items that will pass through the wholesaler to the retailer, it is ultimately borne by the consumer who does not register for VAT purposes and is unable to reclaim it. Hence the incidence falls on the final consumer of the item.

Value Tax System in Nigeria is administered by the Federal Inland Revenue Service (FIRS) in close co-operation with Nigeria Customs Service (NCS) and the State Internal Revenue Service (SIRS).According to section 10(1 and 2) of VAT Act 1993, a taxable person shall pay to the supplier the tax on taxable goods and services purchased by or supplied by him at the time of making payment to a contractor, remit the tax charged on the contract to the nearest local VAT office. The remission shall be accompanied with a schedule showing the name and address of the contractor, invoice number, gross amount of invoice, amount of tax and the month of return. The effectiveness of VAT administration and efficiency in utilizing resources will determine the amount of VAT collected all over the states of Nigeria. The VAT Act empowers FIRS to inspect, audit and investigate businesses for VAT purposes. FIRS appoints an inspector to enter the premises of vatable person without any warrant from time to time in order to ensure compliance with the VAT legislation and regulations in all its remifications; ensure that full amount of VAT deducted are promptly accounted for; examine method of recording transactions and offer suggestion where necessary; afford the VAT payer the opportunity to ask any question and seek clarification as may be necessary; and educate VAT payers on new developments in the system. Naiyeju (1996) as cited by Bassey (2013) stated that VAT audit is the routine verification of the registered person's books and records to ensure the accuracy, completeness and genuiness of the documents on the major aspects of the financial transactions on which the VAT calculations are based.

\subsection{VAT versus Growth and Economic Development of a Nation}

Value Added Tax has been criticized widely and persistently for being unfair to the low income earners and families because it is believed that consumption taxes are regressive, and since Value Added Tax is consumption and hence is regressive. Carlson and Patrick (1998) explained that a tax on consumption repressiveness is based on consumer expenditure studies and surveys showing that the percentage of income spent on consumption declines as income rises. Analysis of Current consumption, in other words, tends to absorb a higher fraction of current income at low income levels than in the middle or upper income ranges. Since every buyer in the market operate in the same market and are charged the same rate, though the total incidence now depends on the quantum of items purchased. It is argued that a Value Added Tax is regressive because it is virtually identical to a retail sales tax. Presently in the global economy, VAT is the most important taxing system of the world, whether the country is developed or developing. Cnossen (1998) as cited by Jalata (2014) said the nearly universal introduction of the VAT should be considered the most important in the evolution of tax structure in the last half of the twentieth century. James (2011) as cited by Jalata (2014) said VAT as consumption tax was considered and spread globally since it appropriately matched to the revenue needs of states in an increasingly globalized economy even if this depends upon each country's policy, and recently some commentators of the tax system shows that VAT directly related to the country's growth and development. Historically, the Federal Government of Nigeria introduced VAT in 1993 to enhance the revenue base of the nation for economic growth and development of Nigeria. According to United States Agency for Industrial Development (USAID) (2014), Economic growth can be defined as a situation of increase in per capital national output or net national product over a long period of time. Growth depicts that the rate on increase in total output must be greater than the rate of population growth. They further explained that economic development is the development of economic wealth of countries or regions for the well-being of their citizens. That is to say that economic development seeks to improve the economic well-being and quality of life for a community by creating jobs and supporting or growing incomes. Economic development implies improvements in a variety of indicators such as literacy rates, life expectancy, and poverty rates. This is to say that economic development encompasses policies that governments undertake to meet broad economic objectives such as price stability, high employment, expanded tax base, and sustainable growth.GDP is a specific measure of economic welfare (Abata, 2014). Abata further explained that economic growth is the growth of an economic output of goods and services which is sometimes referred to as the Gross National Product(GNP). When the growth rate of GNP declines, unemployment results and the income generally falls. When this happens, the government has a duty to set policies that will step up the economy output to achieve sustained economic growth. 
According to Izedonmi and Okunbor (2014), VAT is already a major source of revenue in Nigeria such that in 1994 it was $\$ 189$ billion which is $36.5 \%$ higher than the projected $\$ 6$ billion for the year. VAT revenue for 1995 was $\$ 21$ billion compared with the projected $\$ 12$ billion. That VAT contribution to Nigeria Federal Revenue in 1994 and 1995 were $4.06 \%$ and $5.93 \%$ respectively.N404.5billion collected in 2008 was $5.1 \%$ of total revenue. From 1993 to date, VAT rate is $5 \%$ on purchases. Jalata (2014) stated that in Ethiopia, the adoption of VAT to replace the outdated general sales tax in January 2003 became the central landmark tax reform, which introduced uniform standard rate of $15 \%$ VAT system on most of goods and services. That the growth rate of VAT in Ethiopia was $66.27 \%$.After the execution of VAT, the growth rate of GDP which was $2.53 \%$ reached $21.9 \%$ on average. Sanni (2012) stated that Nigeria adopts the single rate of $5 \%$ of the value of all taxable goods and services which is the world lowest VAT rate. That attempt by the National Assembly to increase the rate of VAT to $10 \%$ was unsuccessful. He explained that the Federal Government of Nigeria has not been able to achieve its policy of increasing the VAT rate. The arguments of those who are opposed to the rate increment have always been that Federal Inland Revenue Service (FIRS) should strive to expand the coverage of VAT to those who are presently out of the tax net and generally increase compliance level. The agitation to increase the VAT rate has not met the support of legislative house, even though the argument to expand the coverage is valid, the subject of revenue expansion can only be met if the VAT is reformed in accordance with the pace of development in the global economy. "Among several different tools that governments use in order to boost the economic growth and development (Rias and Amiri-Aghale,2013), VAT is considered as one of the most common ones. Some governments justify the introduction of VAT by claiming that the revenues from VATwill be used toward developing the infrastructures"

\subsection{The Problem Statement}

The economic development and growth of any nation depends on government ability to generate adequate revenue in order to effectively provide various infrastructural facilities to satisfy the needs of the population and takes its position among the nations in the global village. According to Ogbona and Ebimobowei (2012:62) a tax system offers itself as one of the most effective means of mobilizing a nation's internal resources and it lends itself to creating an environment conducive to the promotion of economic growth. All over the global village, tax is a major source of revenue for the government to provide their statutory roles of creating good living conditions for the citizens. Value Added Tax (VAT) was introduced by the government of Nigeria to enhance the incomplete tax structure and enjoy the benefits accrued to other countries that had implemented VAT. Since the introduction it has contributed quantitatively to the total income generated by the government. There have been various amendments to the VAT Act since its inception. It was chargeable and payable on goods and services listed in column A of Schedule 1 and 2 while Schedule 3 contained the list of exempted goods and services. According to Jalata (2014) the original designed contained 17 chargeable goods and 24 chargeable services, and when new policy to expand the base of VAT was made, new design was adopted which imposed tax on the supply of all goods and services other than the ones listed in the schedule to the Act. The new policy changed the standard for determining chargeable goods. The bright line rule for determining whether a particular good or service is taxable under the extant law is whether it is specifically exempted in the first schedule. Without any specific exemption, the good or service will be taxable thereby giving the tax a very wide base (Sanni, 2012). The section 3 parts I and II of the Act exempt some listed goods and services but the scope of the exempted goods and services were not clearly defined. The statute or the Federal Inland Revenue Service (FIRS) circulars failed to explain the scope of some terminologies like "basic food", "medical services".

Twenty two years after the introduction and implementation of VAT in Nigeria economy, the $5 \%$ charge on value of taxable goods and services remain the same. Ethiopia a country in Africa introduced VAT in 2003 with a standard rate of $15 \%$ and has achieved a growth rate of $66.27 \%$.Advanced countries in Europe and America charge between $10 \%$ and $15 \%$ (Jalata,2014).Various attempts by the Federal Government to increase VAT rate to at least $10 \%$ have not been successful because of the politics involved as the thinking effect of the increase on the purchasing power of the people especially the high income earners who believe they would be negatively affected. The opposition was extended to the argument of some exempted goods and services which should be reviewed as against the increase in VAT rate. The opposition however failed to analyze the fact that the main source of revenue for the federation is shaking due to global glut in the oil industry. Another factor which the opposition failed to consider is that majority of developed countries derive their internally generated revenue from sales tax or purchase tax. Table 1 below shows sampled VAT rates of some countries in the world. 
Table 1. Countries VAT Rate

\begin{tabular}{|c|c|c|}
\hline No & Country & Rate $(\%)$ \\
\hline 1 & Albania & 20 \\
\hline 2 & Algeria & $17 ; 14$ on basics, $7 \%$ on construction \\
\hline 3 & Angola & 10 \\
\hline 4 & Argentina & $21 ; 10.5$ on medical, construction etc \\
\hline 5 & Australia & 10 \\
\hline 6 & Austria & $20 ; 10$ on foodstuffs, hotels; 12 on wine \\
\hline \multirow[t]{2}{*}{7} & Belgium & $21 ; 6$ on medical, housing and construction \\
\hline & & 12 on restaurants and social housing \\
\hline 8 & Benin & 18 \\
\hline 9 & Brazil & $19 ; 12$ on interstate supplies \\
\hline 10 & Burkina Faso & 18 \\
\hline 11 & Cameroon & 19.25 \\
\hline 12 & Canada & $0-20 \%$ \\
\hline 13 & Cape Verde & 15 \\
\hline 14 & Chad & 18 \\
\hline 15 & Chile & 19 \\
\hline 16 & Colombia & 16 \\
\hline 17 & Congo Democratic Republic & 16 \\
\hline 18 & France & $20 ; 10$ on hotels, foodstuffs \\
\hline 19 & Gabon & 18 and 15 \\
\hline 20 & Germany & $19 ; 7$ on hotels and cultural events, 5 on farming \\
\hline 21 & Ghana & 17 \\
\hline 22 & India & 12 to 15 \\
\hline 23 & Indonesia & 10 \\
\hline 24 & Jamaica & 16.5 \\
\hline 25 & Japan & 8 \\
\hline 26 & Malaysia & 6 \\
\hline 27 & Pakistan & 17 \\
\hline 28 & Russia & 18 \\
\hline 29 & Uganda & 18 \\
\hline 30 & Ukraine & 20 \\
\hline 31 & United Kingdom & 20 \\
\hline 31 & Uruguay & 22 \\
\hline 32 & Uzbekistan & 20 \\
\hline 33 & Zambia & 16 \\
\hline 34 & Zimbabwe & 15 \\
\hline 35 & Sweden & 25 \\
\hline 36 & Tunisia & 18 \\
\hline 37 & Norway & $12-25$ \\
\hline 38 & Hungary & 27 \\
\hline 39 & Code D'ivoire & 12 \\
\hline 40 & China & 17 \\
\hline
\end{tabular}

Source: United States Council for International Business (2015) 
From the table, no country of the world is charging as low as $5 \%$ which is the current rate being charged by Nigeria. Majority of the countries charge above $15 \%$, which made the contribution in some to be very significant and in some the principle of equity, takes place.

According to the Value Added Tax Act(1993), a taxable person is obliged to register the business with Federal Inland Revenue Service for VAT collection within six months of the commencement of business. The challenge of improper records of retail traders of not keeping proper records of accounts make VAT collected by them as Non-remittable. Aberuagba versus Attorney General of Ogun State (1995) as cited by Sanni (2012) enunciated on this challenge. The challenge of tax evasion becomes very strong in this situation and it will be difficult to term it as criminal since they are not registered with FIRS. Only registered agents can be accountable to the government for the VAT collected. To strengthen this act, the Nigerian Accounting Standard Board (NASB repealed) did not support VAT accounting and collection with any standard other than the standard and principles of keeping accounting records.

The granting of autonomy to Federal Inland Revenue Service under a separate statute which separated their power from Federal Board of Inland Revenue (FBIR) which was established under Companies Income Tax Act created a scope for adequate administration of VAT. However, with the undertone of VAT evasion, there is still a challenge of ineffectiveness in the Integrated Tax Offices (ITOs).The economy continues to lose huge amount of revenue through the unwholesome practice of tax avoidance and tax evasion, and these loss of revenue can change the fortune of many economies particularly developing countries like Nigeria (Okoye and Gbegi,2013). They explained that corruption cannot be separated from the ineffectiveness and inefficiencies in the tax administration. The integrated tax offices hide under the umbrella of poor facilities to support the argument in giving excuses for poor tax administration and corrupt practices. There are certain conditions against which taxes are judged to be efficient or effective which can be mentioned as fairness, equality, equity, convenience, certainty, flexibility and productivity. It is expected that where the majority of the tax-paying public suffer the same relative amount of pain in paying their taxes, or where the majority of the population do not feel that they are cheated by way of tax then the tax is taken to be good, effective or efficient. (Tamunonimim and Masa, 2012:339). In articulating their points, and in assessing the problem of developing countries especially Nigeria, they stated that it is very difficult to measure the effectiveness and efficiencies of tax especially with regards to the economic and social goals, benefits received because of the clear problem of record-keeping of tax paid or levied due to corrupt practices. Tax players complain of no visible project to account for tax paid that could alleviate their problems.

Okigbo(1992) as cited by Mimiko (1997:3) stated that it is obvious that growth conceived as expansion in the productive capacity of an economy, and developing as improvement in the quality of life of the citizenry, a growing economy may not necessarily be developing; and that basically it implies that growth is a fundamental pre-requisite for development, it is not a sufficient condition. This paper therefore is to assess if Value Added Tax has contributed to growth and development of Nigeria economy since it was created by an Act, and the need for general reforms in order to meet the objectives of the tax system and reduce much reliance on revenue from oil aligning with the developed nations which placed much priority on tax income. Bickersteth (2016) explained that Nigeria has derived a large sum of revenue from oil and gas, with crude oil trading over $\$ 100$ per barrel during the first half of 2014, and the country attained a position of the largest economy in Africa, and comfortable but wasteful in resource management. The global oil glut has adversely affected the revenue position of Nigeria. The over $60 \%$ drop in oil price to below \$40per barrel was unanticipated by the government. This has resulted to over $80 \%$ fall in the yield(spread) per barrel of oil produced in Nigeria, steep decline in the country's revenue,2016 budget deficit of over N2trillion,continuing devaluation of the Naira, slowing GDP growth, reduced inflow of foreign direct investment, rising inflation and growing unemployment. The government at the federal level has put a stop on capital projects, while allocation to the states of the federation has reduced resulting in the inability of many states to pay workers' salaries ranging from five months to eight months (Bickersteth, 2016). The Nigerian government dependent on only revenue from oil and gas, the mono-product of the federation, for foreign exchange and budgetary revenues has adversely affected sustainable growth of the economy. It is therefore very clear to diversify the revenue base of the nation, and Value Added Tax (VAT) is a major revenue source of advanced nations of the world, which much attention is not focused on by the federal government of Nigeria.

\subsection{The Objective of the Study}

The objective of this paper is to evaluate if Value Added Tax contribution to the growth and development of Nigerian economy will necessitate a reform. 


\subsection{Hypothesis}

The study hypothesis stated in null is-Value Added Tax has no significant contribution to the growth and development of Nigerian economy to necessitate a reform.

\subsection{Operationalization of Variables}

$\mathrm{Y}=\mathrm{f}(\mathrm{X})$

$\mathrm{Y}=$ Dependent variable

$\mathrm{X}=$ Independent variable

$\mathrm{Y}=$ Gross Domestic Product (GDP)

$\mathrm{X}=$ Value Added Tax $(\mathrm{VAT})$

$\mathrm{GDP}=\mathrm{f}(\mathrm{VAT})$

This means that Gross Domestic Production position in the economy depends on the performance of Value Added Tax in Nigeria economy. Any action/decision that must be taken on this major source of income depends on the historical performance, which can be used to predict the future of both variables.

\section{Empirical Review/Literature Review}

Tamunonimim and Masa (2012) explained that taxation over the years has been a veritable source of funding public sector activities as well as being an economic tool for the management of the consumption, investment and production pattern. They averred that in developing countries, the imposition of various forms of taxes has been without some forms of feedback on the effectiveness /efficiency of taxes. In the paper, they explained further that tax is a compulsory payment made on different bases and rates by citizens to government which is not negotiable but obligatory. They explained that the usefulness of taxes can be measured by several parameters with its revenue generating capacity and its impact on the consumption and savings patterns in the economy. Further that if the totality of tax system cannot be measured, the various types of tax can be subjected to this measurement. They opined that using the benefit-received approach, taxation might be adjudged to be inefficient since the tax payers can hardly trace the taxes paid to any meaningful project that positively impact on their welfare. However, on the basis of the economy, tax system could be judged affective and efficient if the cost of administering the tax is lower than the revenue derived from the imposition. They based their study on the appropriateness of tax system with reference to the revenue generated in relation to the national income and the respective rates, as well as the assess the appropriateness of tax system with reference to the revenue generated, the consumption expenditure and the standard tax rates. The study appraised the Value Added Tax between 1994 and 2004 (ten years) to determine efficiency and effectiveness of of tax system against the national Gross Domestic Product. Using the percentage ratio system for the study, they discovered that: Value Added Tax system was neither effective in generating revenue for public sector activities, nor was it efficient in directing the consumption pattern of the economy when appraised with the gross revenue. They recommended that Federal Inland Revenue Service in Nigeria should be keeping record and proprietary conscious such that the annual budget of the authorities should be funded from the tax revenues they collect while a target amount is paid to the government.

Sanni (2012) in his theoretical paper that discussed thrust and evolutionary path of the changes to the legal and administrative framework of VAT stated that the relative success of VAT in Nigeria has surpassed the expectations of all sceptics including the International Monetary Fund (IMF) and emerged as a significant source of income for all the levels of government. That the current policy is to gradually reduce the rate of income tax while focus has been shifted to indirect taxes, especially VAT. He explained further that the avowed policy of the Federal Government to increase the VAT rate from the current 5\% has not been successful due to social and political environment, and the opposing opinion has been that instead of increase in rate, the Federal Inland Revenue Service (FIRS) should strive to expand the coverage of VAT to those who are presently out of the tax net and generally increase the compliance level. That with the authority granted FIRS under a separate statute, they have been re-inventing in terms of dynamism and professionalism which should give better administration to Value Added Tax. He explained the following areas that need attention: the need to make the scope of tax more definite rather than open-ended, abolition of branch registration, the need to redefine input VAT in a manner that will ensure that businesses do not bear any burden of VAT by making it possible for them to net off their input VAT; exempt the retail stage in the informal sector of the economy until the commercial activities at this level becomes fairly well regulated and streamline the gap between law and practice. 
Okoye and Gbegi (2013) opined that most economy relies on income from taxation for its development, and that in addition to its use as a means of raising government revenue, it is also often used as an instrument of regulating the economy; redistribute wealth and inducing preferred modes of behavior, particularly consumption patterns and investment choices. They averred that the attitude of Nigerians towards paying tax is worrisome as the economy continues to lose huge amount of revenue through the unwholesome practice of tax avoidance and tax evasion. This attitude can have negative impact on the fortune of economies particularly the developing countries like Nigeria. They further explained the weighty cost of tax collection which may outweigh the benefits derived. Corruption is another factor they capitalized on tax officials connived with supposed tax payers to deny the government their legitimate income. Their empirical study revealed that revenue generated through VAT has a significant influence on wealth creation in Nigeria and on total revenue generated in Nigeria. In their recommendation, they pointed out that Federal Inland Revenue Service should pay attention to the informal sector of the economy by creating VAT offices at the Local communities so as to generate more revenue and to fully achieve the objectives of wealth creation through VAT.

Izedonmi and Okunbor (2014) reiterated that VAT has become a major source of revenue in many developing countries, and that VAT has become an important contributor to total government tax revenues. They stressed that in 1982 VAT accounted for about $30 \%$ of total revenues in Cote d'Ivoire, Kenya and Senegal. Indonesia introduced VAT in 1983 and by 1988, the ratio of VAT revenue to GDP had risen to 4.5\%.VAT in Nigeria accounted for 4.065 in 1994 and 5.93\% in 1995.In their paper, they examined the contribution of VAT to the development of the Nigerian economy. They found out that a positive and insignificant correlation exists between VAT revenue and GDP. They were of the opinion that administrative loopholes should be plugged for VAT revenue to continue to contribute more significantly to economic growth of the country.

Jalata (2014) explained that the achievement of economic growth is crucial for countries sustainable development, and VAT has recently become a major worldwide tax instrument which enhances economic growth. He reiterated that adoption of VAT in Ethiopia to replace the outdated general sales tax in January 2003 became the central landmark tax reform. That with 15\% VAT system on most goods and services in Ethiopia, it has contributed to the boosts of the general economic growth of Ethiopia. He explained further that during the review carried out, the growth rate of VAT was $66.27 \%$ on average. After the introduction of VAT, the growth rate of GDP was $21.9 \%$ on average from $2.53 \%$ before the introduction of VAT. That average ratio of VAT to GDP became $2.95 \%$.The paper concluded that the VAT administration must be strong and requires tax payers cooperation for its effectiveness.

Olatunji (2013) stated that it was the terrible period of revenue slump from petroleum which then dominated the revenue realized by the Federal Government of Nigeria that led to the establishment of VAT. This was based on the financial advice from International Monetary Fund (IMF) and International Bank for Reconstruction and development (IBRD) that are responsible for Structural Adjustment Programme in member countries. Olatunji determined the impact of VAT on the revenue generation in Nigeria and the perception of the citizen on VAT and Inflation. The objective was to move away from crude oil sales, oil royalties and petroleum profit tax which were vulnerable to international petroleum price fluctuation, to a more stable internally generated revenue service. The study adopted both primary and secondary data. He used descriptive approach and tested three hypotheses. The study found out that there is significant correlation between VAT and total revenue of the federation. He averred that VAT has not affected the increase or decrease in inflation rate. Among others, the study recommended openness and accountability in the administration and management of VAT. That for a success of any fiscal policy, it must be properly planned. However, the study did not give room for review of the VAT system in case of changes in economic indices for growth and development.

Adereti, Adesina and Sanni (2011) evaluated the contribution of VAT to the economic growth of Nigeria, and asserted that FGN introduced VAT to increase the revenue base of government and make funds available for development purposes that will accelerate economic growth. VAT introduced in many developing countries has become a major source of income. They were of the view that while the performance of VAT became a source of revenue in Nigeria, it remained difficult to systematically assess the input on the economy. Using time series data on the GDP,VAT revenue and Total Tax Revenue, the regressed data showed that $12.4 \%$ contribution from VAT to Total Revenue was too low compared to about 30\% contribution in Cote d'Ivoire, Kenya and Senegal in 1982.Though a positive and significant correlation exists between VAT revenue and GDP, there were some loopholes that needed to be blocked for VAT to contribute more significantly to economic growth of the country. The study admitted the low contribution of VAT to Nigeria economy, but failed to recommend a reform in the VAT system. 
Njogu (2015) stated that VAT was introduced with a standard rate of $17 \%$ percent, but with other 14 rates that made the VAT appear more like a differential community tax regime in Kenya. He was of the view that the analysis of the efforts of tax policy is critical for government decision makers and the public to make informed policy decisions. This concern over the economy wide impact of VAT is all the important because the possibility that the tax may cause consumers to reduce their consumption of certain commodities that have direct and/or indirect effects on labor productivity. The study used secondary data of VAT rates, GDP growth rates, consumer price indices and unemployment rates. The regression model used showed that there is a significant negative relationship between VAT rates and GDP.He was of the opinion that Kenya Revenue Authority should strive to reduce/maintain a low VAT rate in order to increase GDP of Kenya. This is however in contrast to this study in hand where the VAT rate in Nigeria is $5 \%$,as against $17 \%$ in Kenya.

Omesi and Nzor (2015) opined and explained that the major challenge facing Nigeria's economy is diversification of revenue from oil base, which has become imperative because the reliance on crude oil earning can no longer give a sustainable growth to the economy. This might lead to the grounding of the economy if proactive efforts were not made towards diversifying the revenue base. Though Nigeria is richly blessed with oil and gas, but the overdependence on oil revenue for national growth has affected the economic condition of the nation. International oil customers and consumers of Nigeria like United States of America and others have diversified their customer base and shifted the reliance on Nigeria oil. The paper though theoretical gave an analytical review that since the introduction of VAT in Nigeria in 1994,the rate remains at 5\%. That every attempt to increase it has always been met with oppositions. According to Obadan(2015) as cited in Omesi and Nzor (2015) some European Union Countries and Non-European countries have rates between 10 and 25\%. Omesi and Nzor were of the opinion that Value Added Tax Act LFN 2004 (as amended) needs amendment in order to impose VAT on imported services rendered by a non-resident company outside Nigeria. The Act does not impose VAT on imported services rendered by a foreign company outside Nigeria. They recommend that the government should increase VAT rate to $10 \%$, that government should ensure the informal sector is taxed, and that there should be reform every two years in relation to economic growth. This paper is in the direction of the work of Omesi and Nzor, however, it went further to make the study empirical in order to fill the gaps identified among which is total reform of VAT system.

Bakare (2013) explained that in countries where VAT has been introduced, it has contributed immensely to the growth of each economy but, the accuracy of the growth could not be determined. His study investigated the enormity of the impact of the Value Added Tax on output growth in Nigeria. Using secondary data and regression model, the study found out a positive and significant relationship between Value Added Tax and output in Nigeria. He explained that the results of the findings that the past values of VAT could be used to predict the future behavior of output growth in Nigeria. He concluded that VAT has the potential to assist in the diversification of revenue sources, and provide enough funds for economic growth and development, and reduce dependent on oil for revenue. While the study believed that VAT and economic growth are interrelated, the predictability of the future must be supported with review and reform if we are to achieve sustainable economic growth. This paper was designed to fill the gap.

Unegbu and Irefin(2011) asserted that VAT as a source of income since 200` had been on the increase, and focused the study on economic development of emerging nations with emphasis on impact of VAT on human and economic developments of the States in Nigeria.He averred further that huge increase in Federal revenue resulting from expanding VAT base is an indication that the consumption pattern of the generality of Nigerians are on the increase. This however in his explanation means increasing consumption pattern creates markets and induce positive spill-over effects on other economic activities of a nation. He was of the opinion that the Federal Government of Nigeria is saddened with the responsibility of Vat collections and allocations to the various states of Nigeria. They were of the opinion that the citizens perceptions of the impact of VAT on the human and economic developments of the state seemed not to be at par with claims of the state governments. In their empirical paper, they found out that 91.2\% allocations to a state in the federation is very significant on the economic and human development of the State from 2001 to 2009, but the result from the primary sources suggested minimum VAT impacts. They recommended further research work on the impact of VAT on economic and human development to ensure that revenue allocations from VAT should be perceived to have positive impact on the economic and human developments by citizens. This paper is in line with their recommendation to look at the need for reform of VAT.

Onwucheleka and Aruwa(2014) investigated the impact of VAT on the economic growth of Nigeria, and used ex-post facto research method to articulate their position. The employed ordinary least square technique to analyze their data. They discovered that VAT contributes significantly to the total revenue of government and growth of Nigeria, though the increase is not explosive. They were of the opinion in their recommendation that to boost tax 
revenue, government needs to boosts revenue collected from VAT, not by increasing VAT rate of 5\%, but by closing every VAT revenue leakage, sensitizing the management of companies on the need to remit VAT revenue collection and adequate training of staffs of Federal Inland Revenue Service(FIRS). This paper is to bridge the gap of not recommending increase in VAT rate in their work.

Mba and Peter (2015) examined tax reforms in Nigeria with the focus on Value Added Tax and centered the study on the challenge of Nigeria with a monolithic provident of oil and the need to diversity the revenue base. The study which was theoretical argued that Nigeria VAT rate was the least in the world. They recommended that the rate should be increased and VAT act amended. The study was not subjected to empirical analysis. This paper took care of the gap not covered by the study.

Onaolapo, Aworemi and Ajala (2013) examined the impact of VAT in Nigeria revenue, and observed dwindling revenue generation as characterized by annual budget deficits and insufficient funds for economic growth and development. Using ex-post facto research design and with the adoption of stepwise regression analysis, their study revealed that there is statistical significant effect of VAT on revenue generation in Nigeria. They recommended dedication and apparent honesty on the parts of agents of VAT with respect to collection and payment improvement. The way forward to address the dwindling national revenue was not discussed, which this paper was designed to address.

Adebiyi(2014) stated that every taxable person has the statutory obligation to register for VAT like the manufacturers, distributors, importers and supplier of goods and services within six months of the commencement of business. That each taxpayer is obliged to collect tax on taxable goods and services and at the same time pay VAT on taxable goods and services supplied by him. To determine tax payable, each tax payer must take into consideration his output VAT and Input VAT, and the difference between the VAT on supplies made and VAT paid on purchases is paid to the Federal Inland Revenue Service, or to know if there is a refund if the input tax is exceeds output VAT. He was of the opinion that the world is shifting from direct taxation to indirect taxation, where government around the world seeks to derive more revenue. Though the paper is not empirical, he explained the birth of VAT Amendment bill before the National Assembly with the attempt to review the Bill and propose suggestions on the adequacy or otherwise of the amendment proposal. The gap on the reform of Value Added Tax is still outstanding, which this paper is designed to address.

Ishola (2016) reiterated the fact revenue from indirect taxes has been declining over the years from $85 \%$ in 1970 to $12 \%$ in 1980 and $13 \%$ in 1990, and that government needed a revenue source that would help in turning around this trend. He explained further that VAT has the tendency to generate a lot of revenue since the incidence falls on the consumer who hardly knows that he is paying the tax, provides incentives for exports, enhances balance of payments position, and services as a gauge of the economic health of the country. He stressed further that when the earning power increases it is immediately reflected in VAT proceeds. He therefore stated the weaknesses of VAT to the following reasons: compliance and returns by numerous collecting agents is a difficult task, smuggled goods are not captured into the system and the informal sector of the economy are yet to be captured. The discussion is vital to the reform of VAT, which this paper is designed to resolve.

\subsection{Legal Framework}

According to Federal Inland Revenue Service-FIRS (1999) the idea of introducing VAT in Nigeria came from the Report of the Study Group set up by the Federal Government in 1991 to review the entire Tax System. VAT was proposed and a Committee was set up to carry out feasibility studies on the implementation. In January 1993, Government agreed to introduce VAT by the middle of the year. It was later shifted to 1st September, 1993 by which time the relevant legislation would have been made and proper ground work done. That VAT was a replacement of the existing Sales Tax which was in operation under Federal Government legislated Decree No.7 of 1986 but is operated on the basis of residence. According to Sanni (2014),no reference was made in Constitution of the Federal Republic of Nigeria,1999 and the previous constitutions. That VAT decree 1993 consisted 42 sections and three schedules, but the VAT Act,Cap VI, Laws of the Federation ,2004 consists of 47 sections with one Schedule which contains a list of goods and service exempt. He further stated that not all goods and services are taxable under the VAT Act in the consideration of social, political and economic development of Nigeria. Section 3 of the Act exempts the following goods from VAT: all medical and pharmaceutical products, basic food items, baby products, all exported goods etc. The following services are also exempt from VAT: Medical services, services rendered by Community banks and Mortgage Institutions, Plays and performances conducted by educational institutions as part of learning, and all exported services. The following are zero rate goods and services: Non-oil exports, goods and services purchased by diplomats, goods purchased for use in humanitarian donor funded projects. Sanni explained 
that Nigeria adopts the single rate of 5\% of the value of all taxable goods and services which is the world lowest VAT rate. "A registered person will pay $5 \%$ on goods and services purchased but can claim credit for this tax (called input tax) when sold. 5\% VAT (called output tax) is included in the price of all goods and services supplied by the registered persons" (FIRS,1999)

FIRS stated further that the VAT system in Nigeria is administered by the Federal Inland Revenue Service (FIRS), through the VAT Directorate which is located at the Head Office in Abuja with a network of Zonal and Local VAT offices throughout the Federation. Although VAT is administered centrally by the Federal Government using the existing tax machinery of the FIRS in close co-operation with the Nigeria Customs Service (NCS) and the State Internal Revenue Services (SIRS), the net proceeds from the new tax accrue largely to the State and Local Governments after making a relatively small percentage to the Federal Government to cover the cost of administration. In effect, the State and Local Governments will benefit more out of the entire VAT collection. FIRS discussed a Vatable person as one who trades in vatable goods and services for a consideration. Every vatable person has an obligation to register for VAT operation. The registration is to cover all the business activities of the vatable person. The person can be a sole proprietor (e.g. a trader); a professional (e.g. a lawyer); a partnership (e.g. Ibrahim and Mike \& Co.); a Limited Liability Company (e.g. E. Afe Consultancy Ltd or T. Ade Plc); a Club or Association or a Charity. Every vatable person is to remit to the relevant Local VAT office the net VAT payable which is the excess of the output tax over the input tax while filing the VAT return. Remittances for each month are supposed to be made through the FIRS designated banks to the Local VAT offices which can only issue receipts on confirmation of such payments.

According to sanni (2014), the ACT as enunciated by FIRS the following offences were created in order to punish defaulters and minimize evasion; furnishing of false document, evasion, failure to issue tax invoice, resisting an authorized officer of the FIRS, issuing of tax invoice by an unauthorized person, failure to register, failure to keep proper record and accounts, failure to collect tax, failure to submit returns, aiding and abetting commission of offences. Each offence will attract a fine or imprisonment depending on the gravity. These offences carry penalties ranging from fines of up to N10,000 to various terms of imprisonment. In some cases the fines or penalties depend on the amount of evasion involved. The law is even more strict in dealing with officers of the Board. Any officer of the Board who aids or abets the commission of any of the offences under the VAT law will be liable to a fine ofN50, 000. 00 and/or imprisonment for five years The VAT ACT according to Ishola (2016) stipulates that authorized inspectors from the local of office(Integrated Tax Office) will from time to time visit every vatable person to: ensure compliance with the VAT legislation and registration in all its ramifications, ensure full amount of VAT deducted are promptly accounted for, examine method of recording transactions and offer suggestions where necessary, afford the VAT pater the opportunity to ask any questions and seek clarifications as may be necessary, and educate VAT payers on new developments in the system.

\subsection{Theoretical Framework}

This work is hinged on optimal tax theory of taxation.

Optimal tax theory: Mankin, Matthew and Dany ( 2014) explained that the optimal design of a tax system that interplay between tax theory and tax policy was based on the foundational work of Ramsey (1927) and Mirrlees (1971).That optimal tax theory is based on the following: a. optimal marginal tax rate schedules depend on the distribution of ability; b. the optimal marginal tax schedule could decline at high incomes; c. a flat tax, with a universal lump-sum transfer could be close to optimal; d. the optimal extent of redistribution rises with wage inequality; e. taxes should depend on personal characteristics as well as income; f. only final goods ought to be taxed, and typically they ought to be taxed uniformly; g. capital income ought to be untaxed at least in expectation;8.in stochastic, dynamic economies, optimal tax policy requires increased sophistication. The standard theory of optimal taxation posits that a tax system should be chosen to maximize a social welfare function subject to a set of constraints. It is often that everyone in society has the same preferences over consumption and leisure. The theory posits that the social planner's is to choose the tax system that maximizes the representative consumer's welfare, knowing that the consumer will respond to whatever incentives the tax system provides. After determining an objective function, the next step is to specify the constraints that the social planner faces in setting up a tax system. Mankin et al further stated that Frank Ramsey (1927) suggested one line of attack-suppose the planner must raise a given amount of tax revenue through taxes on commodities only, that such taxes should be imposed in inverse proportion to the representative consumer's elasticity of demand for the good, so that commodities which experience inelastic demand are taxed more heavily. That the social planner need to consider all possible tax schemes, including nonlinear and interdependent taxes on goods, income from various sources, and even non-economic personal 
characteristics. If the social planner is allowed to be unconstrained in choosing a tax system, the problem of optimal taxation becomes too easy. The optimal tax is simply a lump-sum tax. After all if the economy is described by a representative consumer, that consumer is going to pay the entire bill of the government in one form or another. A lump-sum tax accomplishes exactly what the social planner wants. The social planner has to come to grips with heterogeneity in taxpayers' ability to pay. If the planner could observe differences among taxpayers in inherent ability, the planner could again rely on lump-sum taxes, but now those lump-sum taxes would be contingent on ability. These taxes would not depend on any choice an individual makes, so it would not distort incentives, and the planner could achieve equality with no efficiency costs. The optimal tax theory is relevant to this paper as Nigerian government is planning to discover other sources of income to boost the economy, tax on commodity is based on elasticity of demand of individuals and all the eight factors are relevant to the goals of maintaining a sustainable Nigerian economy.

\section{Methodology}

\subsection{Research Design}

We adopted ex-post facto research design for the study. Data from 1994 to 2015 covering twenty two (22) years on Value Added Tax (VAT) and Gross Domestic Product (GDP) on Nigeria economy were obtained and analyzed. Data on VAT for the period were obtained to examine the trend in collection over the years, while Data on GDP for the period were also obtained and analyzed to determine the contribution of VAT to the economic. The decision to study VAT from inception is purposive and judgmental because it would afford us the opportunity to study the trend in the collection and the relationship with the Nigerian economy. The position in the economy would enable us to take a decision if VAT should maintain the status quo or review the existing rate.

\subsection{Method of Data Analysis}

Simple linear regression statistical method was used to analyze the data with the aid of E-View statistical package. Linear regression analysis is a statistical technique that seeks to establish the line of best fit to the observed data. Where the scatter diagram indicates some linearity, linear regression lines are used to predict one variable given the other. The regression line of $\mathrm{Y}($ dependent variable) on $\mathrm{X}$ (independent variable) is generally in the form $\mathrm{y}=\mathrm{mx}+\mathrm{c}+\varepsilon$ where $\varepsilon$ in the error, which if minimized will be zero, resulting in $\mathrm{y}=\mathrm{mx}+\mathrm{c}$. Simple linear also deals with the degree of relationship between variables, where the position of $\mathrm{Y}$ will affect the position of $\mathrm{X}$ positively or negatively. This tool was used to determine the relationship between VAT and GDP over the years in examination. E-view statistical package was used perform the analysis of the data.

\subsection{Model Specification}

$\mathrm{GDP}=\mathrm{f}(\mathrm{VAT})$

$\log (\mathrm{GDP})_{\mathrm{t}}=\mathrm{a}_{0}+\beta_{0} \log (\mathrm{VAT})_{\mathrm{t}}+\mathrm{u}_{0}$

The model is to determine the relationship between Value Added Tax (VAT) and Gross Domestic Period (GDP), if really VAT has any direct relationship with GDP for the period under review that may necessitate the call for a review of the rate charged on consumptions. GDP is an acceptable variable used to measure the performance and growth of an economy, and how each sector in the economy is impacting positively or negatively on the economy of the nation.

\section{Analysis of Results}

This section is divided into two: firstly data obtained were described and secondly, hypothesis developed were tested using ordinary least square regression.

\subsection{Descriptive Statistics}

This paper obtained data for Value Added Tax (VAT) and Gross Domestic Product (GDP) in naira for the period between 1994 and 2015. The trends in the data obtained are shown in figure 1, indicating that both VAT and GDP have upward movement over the period under study. The result of the descriptive statistics of the transformed data is shown on table 1 . There is no much variations in the values of $\log (\mathrm{VAT})$ and $\log (\mathrm{GDP})$ over the years, this is shown by the difference in their respective minimum and maximum values. The skewness of $\log (\mathrm{VAT})$ shows negative this indicates that the left tail is particularly extreme, while $\log (\mathrm{GDP})$ is positively skewed showing that the right tails are extreme. Also, the kurtosis shows that both $\log (\mathrm{VAT})$ and GDP are platykurtic indicating that they have thin tails than normal distribution. Furthermore, the probability of the Jarque Berra statistics shows that both series are normally distributed. 


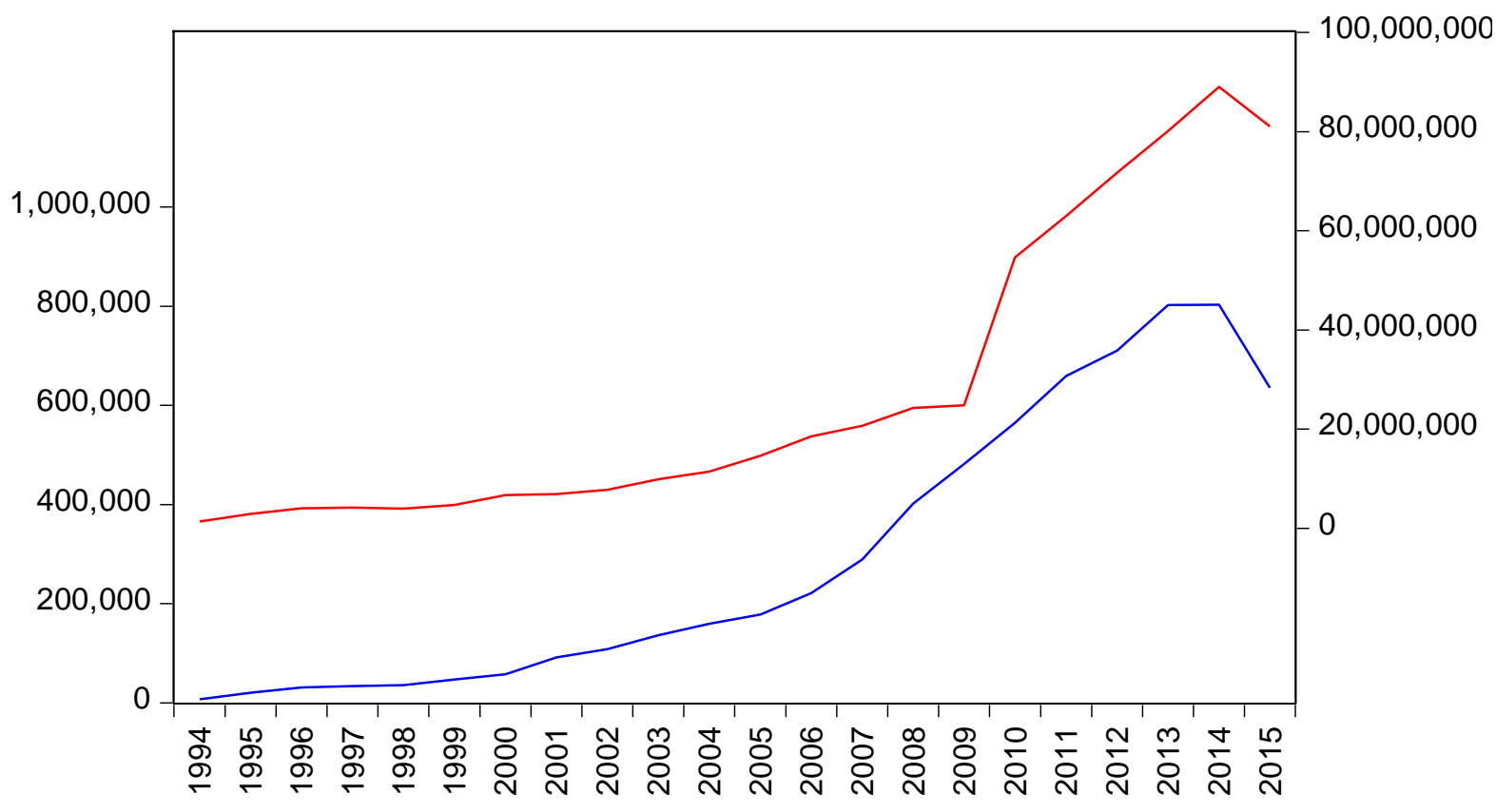

$$
\begin{aligned}
& \text { Value Added Tax (VAT) in Naira } \\
& \text { Gross Domestic Product (GDP) in Naira }
\end{aligned}
$$

Figure 1. Trends of VAT and GDP in Naira

Source: Field Survey, 2016

Table 1. Summary of Descriptive Statistics

\begin{tabular}{lll}
\hline & LOGVAT & LOGGDP \\
\hline Mean & 11.92169 & 16.47410 \\
Median & 12.03495 & 16.37369 \\
Maximum & 13.59607 & 18.30464 \\
Minimum & 8.890273 & 14.15177 \\
Std. Dev. & 1.370616 & 1.239932 \\
Skewness & -0.452359 & 0.045980 \\
Kurtosis & 2.184130 & 1.888923 \\
Jarque-Bera & 1.360480 & 1.139369 \\
Probability & 0.506496 & 0.565704 \\
Observations & 22 & 22
\end{tabular}

\section{Source: Field Survey, 2016}

\subsection{Regression Analysis}

This section establishes the effect of Value Added Tax (VAT) measured by $\log (\mathrm{VAT})$ on Gross Domestic Product (GDP) measured by $\log (\mathrm{GDP})$ for the period between 1994 to 2014. Table 2 shows the regression estimates of the study indicating that $\log (\mathrm{VAT})$ has a positive relationship with $\log (\mathrm{GDP})$. Also, the coefficient of the model indicate that a $1 \%$ increase in $\mathrm{VAT}_{\mathrm{t}}$ will lead to a $0.88 \%$ increase in $\mathrm{GDP}_{\mathrm{t}}$. This shows that there is a perfect positive correlation between VAT and GDP. 
Table 2. Regression Estimates

\begin{tabular}{lllll}
\hline Variable & Coefficient & Std. Error & t-Statistic & Prob. \\
\hline C & 5.935122 & 0.515375 & 11.51612 & $0.0000^{*}$ \\
LOG(VAT) & 0.884017 & 0.042960 & 20.57775 & $0.0000^{*}$ \\
R-squared & 0.954898 & & & \\
Adjusted R-squared & 0.952643 & & & \\
F-statistic & 423.4436 & & & \\
Prob(F-statistic) & $0.000000^{*}$ & & & \\
\hline
\end{tabular}

Dependent Variable: $\log ($ GDP)

*Significant at $5 \%$

Source: Field Survey, 2016

$$
\begin{aligned}
& \log (G D P)_{t}=\alpha_{0}+\beta_{0} \log (V A T)_{t}+\mu_{0} \\
& \log (G D P)_{t}=5.935122+0.884017 \log (V A T)_{t}
\end{aligned}
$$

\subsection{Interpretation and Discussion}

From the regression estimates on Table 2 it can be deduced that Value Added Tax measured by Log(VAT) has a positive effect on Gross Domestic Product measured by $\log (\mathrm{GDP})$. The coefficient of determination indicate that about $95 \%$ variations in $\log (\mathrm{GDP})$ are caused by $\log (\mathrm{VAT})$, this shows that the model has a strong explanatory power. This is further confirmed by the probability of the t-statistics at $0 \%$, implying that the model is statistically significant. Thus, the null hypothesis that Value Added Tax has no significant effect and contribution to the growth and development of Nigerian economy to necessitate a reform is rejected. The result shows that VAT has significant effect and contribution to the growth and development of Nigerian economy to necessitate a reform. Our findings align with the result of Ogbonna \& Ebimobowei (2012) that Value Added Tax has a significant positive effect on Economic Growth of Nigeria.

\section{Conclusion and Recommendations}

\subsection{Conclusion}

From the results analyzed it becomes very clear that VAT has contributed in no small measure to the growth of Nigeria economy.Contribution to growth also affects the development of the economy.However,the detail analysis of table 1 reflects that no country in the world charges as low as 5\% being currently charged by Nigeria.Advanced countries like United Kingdom charges 20\%,Argentina charges $10.5 \%, 21 \%$ and $27 \%$ by classification,Belgium charges $6 \%, 12 \%$ and $21 \%$ by classification,Canada charges between $10 \%, 13 \%$ and $15 \%$ respectively,France charges 20\%. African countries like Algeria charges $7 \% \quad, 14 \% \quad$ and $17 \%$ respectively,Angola-10\%,Cameroun-19.25\%,Chad-18\%,Gambia-15\%,Uganda-18\%,Zambia-16\% and Zimbabwe- 15\% respectively.

This present distress being expereienced globally in the oil industry which has recorded negative effects on Nigeria economy,it becomes very clear that there is the need for the government of Nigeria to look inward towards diversifying the revenue base.Like many countries of the world,reformation of Nigeria tax system becomes imperative. Value Added Tax can gain effeciveness and efficiency if reviewed and well managed. From appendix 1,VAT has been maintaining a steady growth in the contribution to the economic growth of Nigeria.The contribution of $\mathrm{N} 802,964,600,000$ in 2014 dropped to $\mathrm{N} 635,352,000,000$ in 2015 , showing a $20.1 \%$ negative change in its contribution to GDP.This could be attributed to tax evasion,poor management and near neglect in view of the country's reliance on oil revenue.

The relevant literature reviewed adequately covered the importance of VAT to any economy,but this paper went ahead to study and confirm the imperativeness of VAT reform in Nigeria economy inview of the glut in oil income which has been the major source of Nigeria national income.

The paper has made adequate contribution to knowledge through the discovery of optimal tax theory as a basis for charging VAT relativcely on the characteristics of income and taxing of final goods uniformly, which will restrospectively make consumers to pay government bills. The model Log )GDP $)_{t}=\alpha_{0}+\beta_{0} \log (\text { VAT) })_{t}+\mu_{0}$ has been able to predict the imperativeness of VAT reform in view of the dwindling income from oil which can no longer 
support the sustainable growth of nigeria economy beccause the coeeficient of the model indicate that a $1 \%$ increase in VAT will lead to a $0.88 \%$ increase in GDP indicating a perfect positive correlation.

\subsection{Recommendations}

In the light of the above mentioned and analyzed,the following recommendations become imperative for implementation:

1. General reform of Value Added Tax and increase in VAT rate from 5\% which was introduced in 1994,and exacly twenty two(22) years old.Government should consider the increase of VAT rate from 5\% to a minimum of $10 \%$.In facing reality of income objective,VAT should be given priority because from table 1,countries of the world rely on income from VAT to part- develop their economies. The optimal tax theory adopted in this paper support the agenda of reform to increase the social and economic welfare of the nation.

2. Steinmo (1993) stated that "Governments need money,modern government needs lots of money.How they get this money and whom they take it from are two of the most difficult political issues faced in any modern political economy".This statement is applicable to Nigeria today.To achieve this,government should focus on the following areas:

i.Integrated Tax Offices should be strenghtened for efficiency and effectiveness through capacity building in tax administration and information technology leverage.

ii.Federal Inland Revenue Service should address the challenge of tax evasion, which results into narrow tax payer base and reduction in willingness to pay.The implication is reduction in revenue collected against budgeted income.

iii.Government should account for money collected through VAT by the provision of infrastructural facilities to encourage people's willinhness to pay tax.Bickersteth(2016) stated that one of the greatest incentives to paying tax is for the government to use tax revenue judiciously so taxpayer can see the value created by their tax.

iv.Government should enhance efforts to increase the VAT base,as many businsseses are not registered for payment of VAT.The Integrated Tax Offices should reorganise their audit system to visit many enterpreneurs and businsssess.

3. Government should clearly define exempted goods and services from VAT,and bring some of the items hiding under undefined concepts back to vatable items.Most of the countries we reviewed their VAT rates defined good under excemption and those that are vatable.

\subsection{Directions for Future Research}

In view of the fact that VAT is a weapon of fiscal policy and revenue generated is shared among the three tiers of government,further research should be directed towards the states of Nigeria utilization of VAT revenues on the development of the infrastructure of states in Nigeria.

\section{References}

Abata,M.A. (2014). The Impact of Tax Revenue on Nigerian Economy (A Case of Federal Board of Inland Revenue) Journal of Policy and Development Studies, 9(1), 109-121. http://dx.doi.org/10.12816/0011186

Adebiyi,O. (2014). Indirect Taxes in Nigeria.Lagos.Chartered Institute of Taxation of Nigeria (CITN).

Adereti,S.A.Adesina,J.A. \& Sannin,M.R. (2011). Value Added Tax and Economic Growth Of Nigeria. European Journal of Humanities and Social Sciences, 10(1), 455-471

Bakare,A.S. (2013). Value Added Tax and Output Growth in Nigeria.Proceding of $8^{\text {th }}$ Annual London Business Research Conference,Imperial College. London. United Kindom 8-9 July,2013.

Bassey,O.U. (2013). Company and Personal Income Tax of Nigeria,Lagos.Chartered Institute of Bankers Press,Lagos.

Bickersteth,S. (2016). Diversification of the Economy and Sustainable Growth of Tax Revenue:Agenda for Tax.Paper presented at the $18^{\text {th }}$ Annual Tax Conference of The Chartered Institute of Taxation of Nigeria(CITN) 11-14 May 2016 at NAF Conference center,Abuija.

Carlson,G.N. \& Patrick,M.K. (1989). Addressing the Regressivity of A Value Added Tax National Tax Journal, 42(3), 339-351.

Chartered Institute of Taxation of Nigeria (CITN). (2002). CITN Nigeria Tax Guide Statutes Lagos.CITN Publication www.citn.org

FIRS. (1999). Value Added Tax.Information Circular 9991,Ist January,1999. 
Ishola,K.A. (2016). Taxation Principles and Fiscal Policy in Nigeria.Ibadan.Cresthill Publishers Ltd. $1^{\text {st }}$ edition.

Izedonmi,F.I.O \& Okunbor,J.A. (2014). The Roles of Value Added Tax in the Economic Growth of Nigeria British Journal of Economic,Management \& Trade,.4(12), 1999-2007.

Jalata,D.M. (2014). The Role of Value Added Tax on Economic Growth of Ethiopia. Science, Technology and Arts Research Journal, 3(1), 1-16. http://dx.doi.org/10.4314/star.v3i1.26

Jalata,D.M. (2014). The Value Added Tax Styles:Which is Adopted by Ethiopia? Journal of Economic and Sustainable Development, 5(11), 77-81.

Mankinv,N.G.,Weinzierl,M. \& Dany,Y. (2014). Optimal Tax Theory,Harvard University, USA,Cambridge University,UK and Massachusett University USA.

Mba,O.I.\& Peter,N.N. (2015). Tax Reforms in Nigeria:Case for Value Added Tax (VAT). African Research Review. An International Multidiscilplinary Journal,Ethiopia, 9(4), 277-287

Mimiko,N.O.A. (1997). The Global Village-International Economic Relations.ABM Research And Services, Akure-Ondo State.

Njoku,L.K. (2015). The effect of Value Added Tax on Economic Growth in Kenya. International Academic Journal of Economic and Finance, 1(5), 10-30

Ogbonna,G.N.\& Ebimobowei,A. (2012). Impact of Tax Reforms and Economic Growth of Nigeria:A Time Series Analysis. Current Research Journal of Social Sciences, 4(1), 62-68

Okoye,E.I \& Gbegi,D.O. (2013). Effective Value Added Tax:An Imperative for Wealth Creation In Nigeria. Global Journal of Management and Business Research, 13(1), 90-97.

Olatunji,O.C. (2013). Value Added Tax and Inflation in Nigeria.Asian Journal of Humanities and Social Science, $1(1), 123-135$.

Onaolapo,A.A.,Aworemi,R.J.and Ajala,O.A. (2013). Assessment of Value Added Tax and its Effects on Revenue Generation in Nigeria. International Journal of Business and Social Sciences, (4)1, 220-225.

Omesi,I.\& Nzor,N.P. (2015). Tax Reforms in Nigeria:Case for Value Added Tax (VAT) African Research Review-An International Multidisciplinary Journal,EthiopiaVol 9(4):277-287.

Onwucheleka,J.C. \& Aruwa,S.A.A. (2014). Value Added Tax and Economic Growth in Nigeria. European Journal of Accounting,Auditing and Finance Research, 2(8), 62-69.

Riasi,A. \& Amiri-Aghale,S.F. (2013). Effects of hypothetical Iranian accession to the world trade organization on Iran flower industry, Consilience. The journal of Sustainable Development, 10(1), 99-110.

Sanni,A. (2012). Current Law and Practice of Value Added Tax in Nigeria. British Journal of Arts and Social Sciences, 5(2), 186-201.

Sanni,A. (2014). Indirect Taxes in Nigeria.Lagos.Chartered Institute of Taxation of Nigeria. CITN.

Steinmo,S. (1993). Taxation and Democracy:New Haven and London: United Kindom. Yale University Press.

Tamunonimim,A.N.\& Masa,A. (2012). Appraisal of Tax System in Nigeria (A Case Study Of Value Added Tax). Research Journal in Organizational Pscchology and Educational Studies, 1(6), 338-344

Unegbu,A.O..\&Irefini,D. (2011). Impact of VAT on Economic Deveopment of Emerging Nations .Journal of Economics and International Finance, 3(8), 492-512.

United States Agency for International Development-USAID. (2014). Economic Assistance. Wikipedia. 
APPENDIX 1 VAT INCOME GENERATED AND GDP.

\begin{tabular}{lll}
\hline YEAR & VAT (N)m & GDP (N)m \\
\hline 1994 & 7,261 & $1,399,703.22$ \\
1995 & 20,761 & $2,907,358.18$ \\
1996 & 31,000 & $4,032,300.34$ \\
1997 & 34,000 & $4,189,249.77$ \\
1998 & 36,000 & $3,989,450.28$ \\
1999 & 47,100 & $4,679,212.05$ \\
2000 & 57,500 & $6,713,574.84$ \\
2001 & 91,800 & $6,895,198.33$ \\
2002 & 108,600 & $7,795,758.35$ \\
2003 & 136,400 & $9,913,518.19$ \\
2004 & 159,500 & $11,411,066.91$ \\
2005 & 178,100 & $14,610,881.45$ \\
2006 & 221,600 & $18,564,594.73$ \\
2007 & 289,600 & $20,657,317.67$ \\
2008 & 401,700 & $24,296,329.29$ \\
2009 & 481,400 & $24,794,238.66$ \\
2010 & 564,890 & $54,612,264.20$ \\
2011 & $659,153.7$ & $62,980,397.21$ \\
2012 & $710,555.1$ & $71,713,935.05$ \\
2013 & $802,683.5$ & $80,092,563.38$ \\
2014 & $802,964.6$ & $89,043,615.26$ \\
2015 & $635,352.0$ & $81,022,130.00$ \\
\hline
\end{tabular}

SOURCE: CBN Statistical Bulletin; Federal Inland Revenue Service 